\title{
Moving Toward Decolonizing and Indigenizing Curricular and Teaching Practices in Canadian Higher Education
}

Julie A. Mooney

\begin{abstract}
In this reflective paper, I interweave autoethnographic personal narrative and critical self-reflection with theoretical literature in order to engage and wrestle with decolonizing and Indigenizing my teaching and curricular practices in Canadian higher education. Acknowledging that walking this path is challenging, I seek multiple trailheads in an effort to access my hidden curriculum, my complicit knowledge, and unsettling moments that have the potential to transform me. My objective is to critically interrogate myself to prepare for respectfully and appropriately moving toward reconciliation in my relationships with Indigenous colleagues, students, and communities, and in my work as a curriculum maker.
\end{abstract}

\section{Research Question}

As a non-Indigenous academic, how can I begin the work of Indigenizing and decolonizing my teaching and curricular practices?

\section{Methodology}

This study uses autoethnography and autobiographical writing and critical self-reflection to explore my stories of experience, as I wonder and learn about decolonizing and Indigenizing my teaching and curricular practices. Through this work a process model developed-Settler Starting Points-that may support non-Indigenous postsecondary educators interested in decolonizing and Indigenizing their own teaching and curricular contexts and practices (See Mooney, unpublished manuscript).

\section{Autoethnography}

"Stories [are] complex, constitutive, meaningful phenomena that [teach] morals and ethics, introduce unique ways of thinking and feeling, and help people make sense of themselves and others" (Ellis et al., 2011, p. 274). Autoethnography is a research methodology that uses self-reflective, autobiographical writing to facilitate the researcher's exploration of their own personal stories of experience, in order to gain insight into cultural experience (Ellis et al., 2011). Among other qualitative methodologies, autoethnography privileges subjectivity and emotion, and acknowledges that the researcher influences the research (Ellis et al., 2011). In this study, I am not seeking "the Truth," but rather I am exploring my stories of experience, as I recall them at this time, in order to examine what meaning I make of them and what that reveals about my tacit and complicit knowledges. Understanding these taken-for-granted ways of 
knowing will help to reveal, to me, my hidden curriculum and, potentially, move me into unsettling moments (Easton et al., 2019) and towards personal transformation.

\section{Methods}

The autobiographical narratives presented in this paper were written iteratively and separately over a period of three years. Reading scholarly and grey literature, that is now woven into these narratives, facilitated my critical self-reflection and supported my ongoing reeducation about Indigenous realities. Initially, these narratives were written as stories of experience. With each review and revision, I incorporated my "for now" analysis-prompted by further self-questioning-into the narratives. The Settler Starting Points process model ${ }^{1}$ that grew out of this autobiographical writing process is represented in Figure 1, and sample questions to facilitate the Settler Starting Points process are provided as prompts in Appendix A.

\section{Context of the Study}

As an educational developer, curriculum designer, and teacher in Canadian postsecondary education for nearly 15 years, and as a non-Indigenous settler scholar, my institutional educational experiences have privileged settler-colonial systems, languages, cultures, epistemologies, and ontologies. In 2015, the Truth and Reconciliation Commission released its final report, raising an alarm for Canadian educational institutions (among other sectors of society), through 94 Calls to Action that urged us to learn the truth about the Indian Residential School system and its genocidal legacy against Indigenous people, their families, and communities (TRC, 2015). In response to these Calls to Action, many Canadian universities and colleges developed strategic plans to "Indigenize" their campuses.

\section{Problem Statement}

Institutional strategic plans to Indigenize do not identify specific tasks or procedures for implementation at the level of teaching and curricula. These strategic documents have been criticized for glossing over the Calls to Action with token responses that fail to engage in the deeper transformational work of decolonizing education and eliminating racism on campuses, at interpersonal and systemic levels (Gaudry \& Lorenz, 2018; Pidgeon, 2014; Todd, 2018). Teaching professors and educational developers, who are largely non-Indigenous people in the context of Canadian higher education, ${ }^{2}$ must find our way into this unfamiliar landscape of decolonizing and Indigenizing our teaching and curricular practices. As non-Indigenous academics, who have often been educated exclusively in Western educational institutions, we are not only unfamiliar with, but likely ignorant and mis-informed about Indigenous knowledges and pedagogies. Further complicating the problematic, "because Indigenous scholars are a minority within Canadian postsecondary institutions, they are often over-relied upon to be the experts on Indigenization" (Mooney, unpublished manuscript). Reconciliation needs to be a process for repairing the broken relationships between non-Indigenous and Indigenous peoples. Settler scholars, like myself, 
need to recognize the ongoing settler-colonial system from which we continue to benefit, to attend critically to the history of extractive and exploitative settler-colonialism, and to take responsibility for our reeducation.

\section{Who Do You Think You Are?}

Before I began exploring Indigenization and decolonization, I tried to stay safely in a less contested, less complicated, and less controversial area of research. I feared the alienation and disruption such research might cause. I feared I was bound to offend, fail, or cause further harm by exploring this challenging subject matter. But settler silence supports the theory of the perfect stranger (Dion, 2007). "Dominant stories that position Aboriginal people as, for example, romanticised, mythical, victimised, or militant Other, enable non-Aboriginal people to position [ourselves] as respectful admirer, moral helper, protector" (p. 331). Through reading and reflection, I realized that my silence, too, has the potential to offend, fail, or cause further harm. Nobody ever said this would be easy.

Since deciding to engage in this research, I have experienced resistance from some Indigenous and settler academics. Settler colleagues who resist this work warn me that it is not valued and it may damage my career prospects. Indigenous colleagues who resist my engagement with this work have asked questions along the lines of, "Why should you have access to our knowledges, our land-based learning, our stories, our pedagogies, our Elders? They belong to us. Who do you think you are?" These are legitimate questions of critical importance for settlers, like myself, to ask ourselves. Exploitative and extractive research by Western academics in Indigenous communities has demonstrated a lack of respect and care for Indigenous peoples and has had damaging effects on settler-Indigenous relations (Hunt, 2018; Kuokkanen, 2007). Moreover, Indigenous scholarship, feminist, antiracist, and critical theories all contest the Eurocentric arrogance that assumes we can know the "other" (Kuokkanen, 2007).

Who do I think I am to write about Indigenizing curricular and teaching practices in Canadian higher education? As a woman of Irish-Scottish ancestry, I am a settler in Canada. Throughout Canada's history, Celtic people have migrated from Ireland and Scotland (and elsewhere) to these lands to make a new life and to prosper in ways that were not possible in our ancestral homelands. While some of my family members and ancestors experienced and (some) fled English colonialism in our homelands, Irish and Scottish people also benefited from settler-colonialism that made way for waves of Celtic people to arrive and settle on these lands. Moreover, Celtic immigrants continue to benefit from the ongoing colonial project that privileges whiteness (white skin), English-language, Christian heritage, and Western institutions and knowledge systems. ${ }^{3}$ Conversely, I must also ask myself, "Who am I not to work toward reconciliation?" Isn't it my responsibility, as a settler, to contribute to repairing and rebuilding the broken relationships between settlers and Indigenous peoples in the territory where I live, learn, and work? 


\section{In What Sphere Do You Have Influence?}

Professionally, I identify as an educator, researcher, and educational developer in the higher education sector in Canada. I have, along with many others, capacity to contribute to the re-visioning and reshaping of postsecondary education. Decolonizing and transforming higher education is especially important in response to the damage that was done to Indigenous peoples and communities through the Indian Residential School system (TRC, 2015). I understand it necessary that I engage in this work alongside Indigenous colleagues, so as to be led by them, and simultaneously not allow the burden of this work to be carried by them alone. "Discouragement and burnout prevail in the meager sprinkling of Indigenous faculty in Canadian universities" (Battiste et al., 2002, p. 92).

\section{How Can I Decolonize My Mind?}

\section{Mis-education}

As a child, I was mis-educated (Dewey, 1938) about Indigenous peoples and their cultures. The French Immersion curriculum of my generation and in my eastern Ontario community presented "les autochtones" (Indigenous peoples) as warriors, sensationalizing their tactics of war. I remember emphasis on Iroquois scalping practices and the violence that was inflicted on Jesuit priests. The stories were taught from French-Canadian and Québécois perspectives, with such a skimming over of other regions of Canada, that I didn't have any consciousness of the different histories and cultures of Indigenous communities in Western and Northern Canada, and very limited knowledge about those in Central and Eastern Canada. What's more, the curriculum made no mention at all of contemporary Indigenous peoples and their (at the time of my public school education) 20th century realities.

In 1990, when the Mohawk people defended their territory and the Canadian Army was sent in to stop them, I was working as a Junior Forest Ranger in Northern Ontario, completely cut off from television, radio, and newspapers. I didn't hear about "the Oka Crisis" until the end of the summer, when I went home to Ottawa, and my Dad joked that I went into the bush for the summer and our country nearly went to war. Though he tried to reassure me, I knew there was some truth in his comment. I wanted to know more about this near-war between Canada and the Mohawk people. I searched newspapers, but information was not digitized like it is now. Information was spotty and I struggled to figure out what the crisis was really about. Even though the Oka standoff continued through September that year, I have no recollection of any teachers discussing it in my public school classes.

As I write my foggy memory of the Oka protests that took place nearly 30 years ago, over the past few weeks, new Indigenous blockades have been established on rail lines across Canada in solidarity with the Wet'suwet'en hereditary chiefs, in northern British Columbia, who oppose the construction of the Coastal GasLink natural gas pipeline ${ }^{4}$ approved to be built across Wet'suwet'en territory (The Canadian Press, 2020). This morning an iconic image of the Oka Crisis was front and centre when I opened the news online. The caption reads, "Sept 1, 1990: Canadian soldier Patrick Cloutier and Saskatchewan 
Ojibway Brad Laroque alias "Freddy Kruger" come face to face in a tense standoff in Kanesatake which began as a land dispute with the municipality of Oka, Que. (Shaney Komulainen/Canadian Press)" (CBC Radio, 2020, webpage). As I read the article, I learn that the Oka protests in 1990 were in opposition to the planned expansion of a golf course (CBC Radio, 2020). Now, 30 years later, Indigenous peoples continue to struggle for respect and recognition of their territories and their laws. Has settler-colonial Canada learned anything in the past three decades?

Slowly, I am working to undo my mis-education, to unlearn my ignorance, and gain understanding about Indigenous struggles for sovereignty and self-determination. What started in my youth as a search for information, has grown into a feeling of personal connection to the issues that matter to Indigenous peoples. I am starting to understand that we are all interconnected and dependent on the land. Without healthy, thriving ecosystems and biospheres, we are in trouble as a species. I was learning those lessons while I planted trees and built salmon spawning beds in the forests and rivers of Northern Ontario, as a Junior Forest Ranger 30 years ago. Now I see that those issues of environmental sustainability can serve as a site for understanding and connection between Indigenous and non-Indigenous peoples in Canada. Perhaps this common ground is a place to start a new relationship with one another, to start the work of reconciliation.

\section{Roadblocks to Ally Engagement}

From 2013 to 2016, I coordinated the establishment of a centre for peace education at a Canadian college. Around the same time, a group of colleagues at the college started discussing and acting on the dearth of supports available to Indigenous students and, shortly thereafter, the TRC calls to action were released (TRC, 2015). I saw the work of improving Indigenous student experiences as consistent with the values and mandate of the peace centre. But when I suggested collaboration between these two initiatives, one of the college's senior leaders, a woman of European ancestry, told me that the Indigenization project is not for me. Aware that such initiatives must be led by Indigenous peoples, I was nevertheless surprised by and did not understand what motivated her exclusionary stance. Decolonizing and Indigenizing postsecondary curricula can be "frightening and counterintuitive" (Regan, 2010, p. 19). "The vulnerability required to reveal to colleagues our ignorance on a subject is not well-practiced in Western academic traditions" (Mooney, unpublished manuscript, n.p.). Nevertheless, settlers need to engage in this work alongside Indigenous people, to earn their trust, to earn the honour of the ally role (Chung, 2019), and thereby contribute to the peaceful and just healing of Indigenous-settler relations.

How can I decolonize my mind and my way of being as a settler in Canada? The obstacles I faced in my youth and, then again in my work with the peace centre, have challenged me, but not stopped me from pursuing my own reeducation. I realize I am deeply embedded in and formed by a settler-colonial society. It is, indeed, difficult to separate myself from Western values, culture, and structures in order to see the world from another perspective, but I need to try. I need to listen to the stories of experience of Indigenous people, wherever and however I can access them (in person, online, in MOOC course materials, through readings, by attending talks by Indigenous scholars, etc.). I need to interrogate my taken-for-granted knowledge and experience, the epistemologies and ontologies that have made me who 
I am, and that permeate my teaching and curricular practices. And, I need to allow Indigenous stories, knowledges, epistemes, and ontologies to reshape my thinking and understanding of myself and our relationships with one another.

\section{Settler Starting Points}

Integrating elements of an Indigenous holistic framework: intellectual, spiritual, emotional, and physical (Pidgeon, 2014) and values consistent with the four Rs: respect, relevance, reciprocity, and responsibility (Kirkness \& Barnhardt, 1991; Marker, 2004), my autoethnographic writing and critical self-reflections led to the development of a process model I have called "Settler Starting Points", 5 shown in Figure 1. This process model is intended for settler engagement in Indigenizing and decolonizing curricular and teaching practices in Canadian higher education. Pidgeon's (2014) Indigenous holistic framework challenges Western academic emphasis on intellectual reason, by valuing a wholeness of human experiences. The four starting points-humility, relationality, responsibility, and land-appear as overlapping and interconnected circles, infused by the values of holistic engagement with mind, spirit, heart, and body. Humility, relationality, responsibility, and land are important values in many Indigenous cultures. By calling on these values as a settler, I do not wish to appropriate Indigenous cultures, but to honour them, and to emphasize these four Settler Starting Points because, as human values, they have largely been forgotten in individualistic, competitive, and capitalistic Western academic traditions. The permeable dotted line, surrounding the overlapping circles, represents Indigenous and settler individuals, communities, students, academics, knowledge keepers, Elders, and administrators working alongside one another to transform postsecondary teaching and learning.

Below are excerpts of my own self-reflective, autobiographical writing, using sample questions as prompts for this exploration. See Appendix A for a list of sample questions to prompt reflection and writing within each of the four rubrics of the Settler Starting Points process model. 


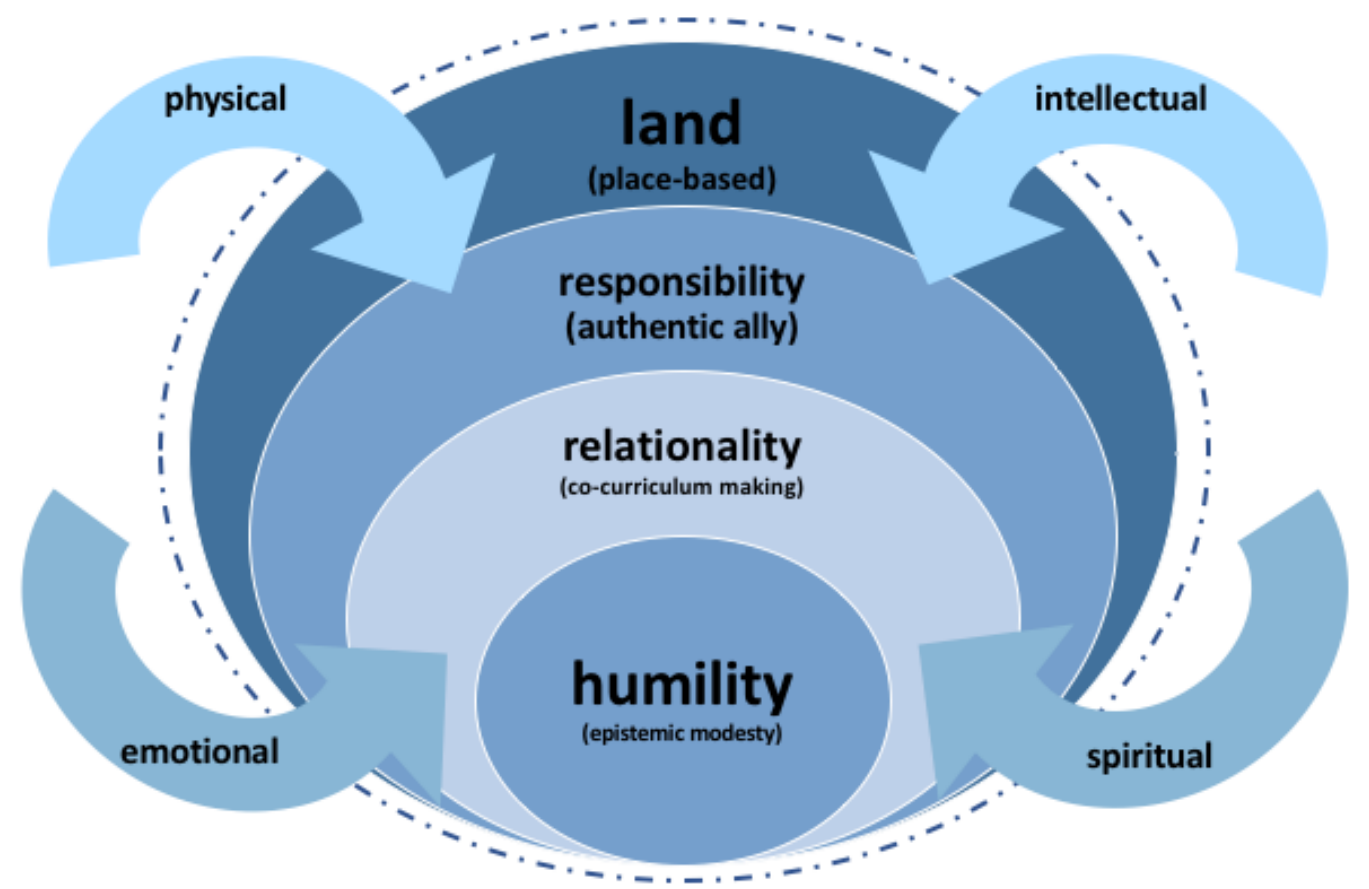

Fig. 1: Settler starting points for decolonizing and Indigenizing curricular and teaching practices in Canadian higher education.

\section{Humility (Epistemic Modesty) Starting Point}

What would happen to me if I were to suspend my critical judgment the next time I felt inconvenienced or my work was delayed by an Indigenous perspective or way of being?

While working as an educational developer at a postsecondary educational institution in Canada, I had the opportunity to lead a study of Berg and Seeber's (2016) book The Slow Professor: Challenging the Culture of Speed in the Academy, for a group of faculty members from across the disciplines. During one of our group discussions, one faculty member commented on how Berg and Seeber's (2016) position reminded her of Indigenous peoples' relationship with time, a slower pace than North American ways. That comment led another book study participant to share the view that the institution's push to Indigenize was unwelcome, making comments that slowing down to accommodate an Indigenous pace is neither practical, nor desirable. The anti-Indigenization comments continued in what I felt was an overtly racist vein and, after they were made, an uncomfortable silence fell upon the group. People started shifting and fidgeting in their chairs. As the facilitator, I paused with the group, waiting, and present to our collective discomfort. I thought to myself, "Nobody wants to be called a racist. Nobody wants to be a racist. How can I help the group through the racist perspective that was just expressed?" I was aware that if the person who had shared that opinion were to adjust her thinking, she would need to feel accepted and safe in the group, not ostracized or shamed.

My initial response was to remind the group that it is my intention to create a safe and confidential space in this book study series, where participants can express their perspectives freely and feel comfortable experimenting with new ideas. "This is meant to be a learning space and we are all here to learn 
together." I acknowledged that learning together sometimes means disagreeing with one another, and that respectful debate could prompt deep learning. There was another long pause in the group after I spoke.

Another faculty member spoke next. He shared with the group that as a gay man he has experienced being excluded on many occasions. While acknowledging that he benefits from many privileges, he began to express to the group how his experiences of oppression have given him insight into what it might be like to experience oppression as an Indigenous person. He spoke about the courage it takes to speak up and make one's presence known when one feels pushed to the margins. He spoke from the heart, in a gentle, non-judgmental tone of voice, and the book study participants listened respectfully. He modelled humility and epistemic modesty to the group, and they took heed to what he said. I wonder if the group would have responded in the same way had he been an Indigenous man speaking about his experiences of oppression and erasure. That said, sharing his experience as a gay, white man with a group of colleagues he had only just met, made him vulnerable. This vulnerability humbled me, and likely others in the group. I had and still have great respect for the way he shared his perspective. One after another, they took turns, gently speaking about their relationships to Indigenous knowledges, their relationships to time, to the Indigenization policies on campus, and about their own understandings of privilege, power, and oppression. It was a difficult conversation, one that I found stressful to facilitate, and one of the most profoundly meaningful group discussions in academia of which I have been a part.

When the meeting ended, people left quietly, not making eye contact. I feared that I might never see them again. We had a number of meetings remaining in the series. I worried about what would happen next, so I preemptively asked to meet with my supervisor, to report what had happened and prepare her for possible complaints. Instead of complaints, I received emails of thanks and appreciation for the depth of discussion that I had facilitated, for the respect and calm I had modelled. I was delighted when everyone returned the next week, including the colleague who had made the initial comment against Indigenization. And people kept coming back week after week for deeply engaged conversation.

As the facilitator, feeling my own discomfort, the dis-ease of the group, and the brewing potential group conflict moved me into a moment of unsettlement (Easton et al., 2019; Regan, 2010). I had to set aside my beliefs about Indigenization, to make safe space for an opponent, in order to support learning. I had to admit to myself that although I found her comments racist, I am not innocent in this racist world, in which white-skinned people, like me, continue to benefit at the expense of Indigenous people and people of colour. I still have much to learn about decolonizing my mind, and eliminating racism. Humility and epistemic modesty are a useful mindset to assume when entering into this personally challenging arena. By emphasizing that we are in a safe learning place, I challenged myself to actually embody that value, to set aside my urge to speak out against racism, and see what we could learn together, when we humbly and gently explore difficult terrain. Together we allowed our thinking to be unsettled; ${ }^{6}$ we became vulnerable and real with one another. To learn to decolonize curricular and teaching practices, I need to face my own prejudice and racism, and to see these qualities in others, without condemning them or myself. I, along with supportive colleagues, need to create safe spaces to work through these aspects of our mis-education, in order to learn better, more just ways of thinking and being. ${ }^{7}$ 


\title{
Relationality (Co-curriculum Making) Starting Point
}

\author{
How might I facilitate re-centering our curriculum processes \\ to support Indigenous ways of curriculum making?
}

While working in a centre for teaching and learning $(\mathrm{CTL})$ at a Canadian postsecondary institution, I had the opportunity to collaborate with two Indigenous colleagues on a workshop. After developing a solid plan, at a subsequent meeting one colleague suggested restructuring the workshop using pedagogies from his community's traditions. This would involve significant changes, including the omission of an introductory activity about which I was excited. I expressed my hesitation, but went along with the suggested changes.

When we delivered the workshop some weeks later, our plan had to change again, because at the opening of the workshop, a participant introduced a local Indigenous Elder, ${ }^{8}$ and asked the group to make time for the Elder to speak. This Elder spoke at length, telling a beautiful story of the land and creatures that make their home in the place where we were meeting. The time that the Elder spent sharing this story enriched the workshop significantly, and I felt deeply grateful for his contribution. However, because of this change in the unfolding of the workshop, time had to be cut from other parts of our plan. Our co-facilitation team spontaneously adjusted the plan, and carried on.

When we debriefed the workshop afterwards, the colleague who had suggested the major changes to our original plan reminded me that I had initially been reluctant about those changes, but when the workshop happened, I showed that I was flexible and open to allowing the experience to unfold organically. In hindsight, reflecting on my participation in that workshop co-facilitation team, I realize that I had certain expectations of what it meant to work collaboratively and how a planning meeting should happen. But when I set aside my attachment to one aspect of our plan, when I prioritized my relationship with Indigenous colleagues and put my trust in their pedagogy-albeit with hesitationI opened myself to Indigenous curriculum making. Thus, my understanding of what it means to Indigenize and decolonize teaching and curricular practices broadened. Indigenization and decolonization are not meant to be easy or comfortable for settlers. When we, settlers, are able to move past our discomfort with and hesitation to Indigenous pedagogies, we have the opportunity to expand our curriculum making in ways that are responsive to learners' needs and learning contexts.

This experience prompted in me the question, "How might I facilitate re-centering curriculum processes to support Indigenous ways of curriculum making?" As I continue to reflect on this question, I hope that the next time I'm in a similar situation, I might be less hesitant to let go of my attachment to an established, familiar plan and process, and open myself to another way of creating learning opportunities. 


\section{Responsibility (Authentic Ally) Starting Point}

\section{Am I appropriating Indigenous cultural practices by incorporating this pedagogy into my work?}

When preparing for an academic presentation, I decided to write a fable based on my tentative theory about decolonizing and Indigenizing the academy. ${ }^{9}$ I shared the fable as part of the presentation and received feedback that it would make a useful educational resource.

While I was writing draft versions of the fable, I had thought deeply about how to write a fable. I had wondered how I might anthropomorphize animals and give voice to the land without it coming across

as or actually being cultural appropriation of Indigenous storytelling approaches. I remembered advice I had received from a Cree-Métis professor during my doctoral studies, when I wondered how to find home and feel a sense of belonging in a place that is not my ancestral homeland, and not the place where I was born. Her response was clear and direct, "Loving the land is a good place to start" (Personal communication, Cardinal, 2018). As I wrote, I made sense of my writing not as a copy of any Indigenous stories I had heard or read, but as a translation of my own tentative theory, in my own voice, and my own words. ${ }^{10}$ I was expressing my deep love for the land where I live and work. What's more, I was writing as a settler for settler audiences, with the hope of creating a learning tool that could serve us all in our work to decolonize and Indigenize ourselves and our institutions.

However, when I shared an early draft of the fable with some of my Indigenous professors and colleagues, their feedback revealed to me some of my own blind spots. Despite my good intentions, their feedback questioned several aspects of the fable, including: the literary genre itself, my representation of specific animals that are sacred to some Indigenous communities, metaphors that, although not intended this way, were interpreted as deficit narratives about Indigenous peoples and saviour narratives about settlers, and the overall tone of the story, which reminded them of various Indigenous stories. I felt embarrassed by my mistakes and for the possibility that I had disappointed my beloved colleagues and professors. Although I was explicitly trying not to appropriate Indigenous culture and wrote deliberately to represent Indigenous people in positive ways, I had failed in my efforts.

Even though I was embarrassed about my fable and the negative messages it had conveyed, I had to keep my commitment to decolonizing myself and repair my relationships with my Indigenous professors and colleagues. One of my professors named that offering candid feedback to settlers about our mistakes is exhausting for her, but she did it for me because she believes my heart is in a good place. She compelled me not to drop this work, but to carry on and do better. And with that, I felt the weight and urgency of my responsibility in this work of decolonizing, Indigenizing, and moving toward reconciliation. I recommit myself to doing better, to not making those mistakes again, and to working to repair any harm my errors had caused in my relationships with Indigenous people.

I have since made major revisions to the fable. It is no longer a fable that anthropomorphizes animals. I am writing a new story, more closely based on my own experience of building relationship with Indigenous colleagues. I am fortunate that my Indigenous professors and colleagues, as well as some 
non-Indigenous peers and mentors, are willing to review and comment on revised versions of the story, to help me develop it in a good way.

\title{
Land (Place-based) Starting Point
}

\author{
What are my stories of experience with this land, in this place?
}

\section{Belonging Now, Here}

A long freight train crossing this vast territory, thunders through the Rocky Mountains, declaring its progress, at intervals, with its haunting horn. It takes more than 30 minutes for the sound of rhythmic rolling to disappear into the distance. I sit in my room at the Banff Centre for Arts and Creativity, reading for and writing my doctoral candidacy proposal. Chung's (2019) autoethnographic writing inspires me to set aside the methods of inquiry section and attend to my own story, here and now, in this beautiful place far away from my daily routines. Visual and performing artist Pascaline Knight's (Knight et al., 2019) interpretation pulls me to think of remote place not as "in the middle of nowhere," but as now here or, as she translates it, ici main-tenant, which might translate back to here, holding hands or here, hand-holding, or here, hand out-stretched. I am an open hand, out-stretched, in this place where I feel a deep belonging. Like the train that lingers, now, here, out-stretched, I want to stay and sing my song, to roll in rhythm with this land, this place.

My return flight is tomorrow afternoon; just thinking of my departure from the mountains sets off a long bleat of the horn in my heart. I don't want to go. I want these mountains to envelope me every day. I want to breathe this mountain air through all her seasons. I want my feet to tread here in the darkness, snow, and silence of January, in the run-off and dirty slush of spring, in the moderate heat of summer, and the waning warmth and lingering light of autumn. I am homesick for this land and place, as I prepare to leave.

\section{Reflecting on Place}

I've had the privilege and the challenge of a fairly nomadic life. When I reached 30 years of age, I had moved 33 times in my life. Since then, I've moved many more times, and lost count. I've made home in five Canadian provinces, and at least eight Canadian municipalities; I have lived and worked in nine other countries, all outside of North America. All this moving around has challenged my sense of home. As I engage in writing and reflecting about decolonizing and Indigenizing curricula, I have been asking myself less and less, "In what land will I make my home?", and more and more, "To what land do I belong" (Chambers, 2006)? I know that my ancestral homelands are in Ireland and Scotland, and I feel a great sense of belonging in those places and on those lands. But I was born in eastern Ontario, I spent significant moments in my childhood there and in rural New Brunswick, and I have since come to feel a strong sense of belonging to the Rocky Mountains, their eastern foothills, and the vast prairie lands that stretch eastward from there. These lands, some on which treaties were negotiated and signed, some that 
remain unceded, continue to be occupied and exploited by Canadian economic interests. Despite the genocidal actions of settler-colonial Canada, Indigenous people remain on their homelands. Their endurance, persistence, and resilience must not go unnoticed. They are working hard to heal themselves and their communities from all the pain and loss settler-colonial Canada has inflicted on them. They are working to recover their languages and teachings, their songs, stories, and dances, their ceremonies and their relationships to the land. I continue to seek ways that I can celebrate and support Indigenous resurgence, while also nurturing my own relationship to the land and its ancestral people, where I live and work.

\section{Closing Thoughts}

Recognizing Indigenization, decolonization, and reconciliation as ongoing, relational commitments, I entered into this autoethnographic, autobiographical project, writing and reflecting to find a useful way into decolonizing and Indigenizing my teaching and curricular practices. Through this study into myself, "Settler Starting Points" emerged as a process model with four possible starting points or trailheads and guiding questions to prompt reflection on humility (epistemic modesty), relationality (co-curriculum making), responsibility (authentic ally), and land (place-based). I sought to interrogate my taken-for-granted knowledge, to enter the uncomfortable, unsettling moments in my thinking and being that need to be transformed, as I work to reeducate myself and prepare myself for living reconciliation. Because this work aims to transform, it is necessarily contingent, and represents my "for now" analysis and understandings (Simpson, 2011).

In this paper, I have highlighted some of my moments of unsettlement. Through the exploration of these stories of experience, I have learned that decolonizing and Indigenizing my teaching and curricular practices is deeply personal work, and needs to occur holistically in mind, heart, body, and soul. Nevertheless, the insights that have arisen from the reflective writing process are only one part of a larger process. As emphasized by Easton and colleagues (2019) and by Yeo and colleagues (2019), I also need to engage in this work in reciprocal collaboration with Indigenous and settler colleagues and in supportive, collegial communities, committed to transformation. 


\section{Appendix A: Settler Starting Points - Guiding Questions for Self-Reflection}

\section{Humility (Epistemic Modesty) Starting Point}

- How might I support the centering of Indigenous knowledges in my curricula and in the learning environments that I facilitate?

- What would happen to me if I were to suspend my critical judgment the next time I felt inconvenienced or my work was delayed by an Indigenous perspective or way of being?

- How might I enact a practice of epistemic modesty in my day-to-day interactions on campus?

- How might I support my students to learn epistemic modesty?

- How might I grow if I were to explore my area of scholarly expertise through my physical senses, emotions, and/or spiritual means?

- How might I learn to recognize and see epistemes that have been rendered invisible through settler colonial epistemic dominance (Kuokkanen, 2007)?

\section{Relationality (Co-curriculum Making) Starting Point}

- With whom am I co-curriculum making?

- Are Indigenous colleagues' curricular contributions at the centre of our curriculum making processes?

- If not, how might I facilitate re-centering curriculum processes to support Indigenous ways of curriculum making?

- What mechanisms do I have at my disposal or might I access to ensure that curriculum making is collaborative and reciprocal between Indigenous and non-Indigenous, settler colleagues?

- With what attitude and disposition do I enter into conversations and interactions with Indigenous collaborators and Indigenous students?

- $\quad$ Do my attitude and disposition differ in my relationships with non-Indigenous, settler colleagues and students?

- $\quad$ Are these differences appropriate, and do they support decolonizing and Indigenizing efforts?

\section{Responsibility (Authentic Ally) Starting Point}

- Am I appropriating Indigenous cultural practices by incorporating this pedagogy into my class?

- If so, how could I incorporate this teaching practice respectfully acknowledging the limitations of my knowledge and authority?

- Who has the required knowledge and authority to teach in this way?

- Could I invite one such individual into the learning experience to lead in this way?

- What Indigenous protocol must I learn in order to invite and welcome an Indigenous Elder, knowledge keeper, or community member to lead in my course?

- What might be too much to ask of Indigenous peoples and Indigenous colleagues?

\section{Land (Place-based) Starting Point}

- What stories of this land, in this place where I live and work, will I choose and from whose perspective will they be told?

- What are my stories of experience with this land in this place?

- How has this land shaped who I have become as a human being and as an educator?

- Rather than asking, "Does this land belong to me?" or "Since when does this land belong to me?" I ask: "How do I belong to this land?" and "How am I in relationship with this land, where I live and work?" 


\section{Notes}

1. For further details about the Settler Starting Points process model, see Mooney (unpublished manuscript).

2. On Canadian campuses, only 1.4 percent of professors identify as Indigenous (Shen, 2018). Faculty positions in Canada are largely held by academics of European ancestry, who experience white privilege, and have been educated exclusively in Western, settler-colonial institutions (Todd, 2017).

3. It is important to note here that the English language, Christian religion, and Western knowledge systems were not originally part of Celtic cultures, but rather British colonizers brought their language, religion, and knowledge systems when they invaded and subjugated Celtic language, spirituality, and beliefs systems. Since then, Irish people in particular have had a complicated and often hostile relationship with Britain, and many Irish people in Ireland and in some diasporic communities continue working to restore and/or preserve Irish language (Gaelic), spirituality, and culture.

4. The Coastal GasLink natural gas pipeline is a key part of the \$40-billion LNG Canada export project (The Canadian Press, 2020). This highly contentious project is being paid for by Canadian taxpayers, following Prime Minister Justin Trudeau's decision to fund the project, which is intended to transport natural gas from Alberta, through northern British Columbia, to the West Coast of Canada for export to international markets. Many Canadians, as well as Indigenous peoples, oppose Coastal GasLink pipeline. Its construction divides communities. On the one hand, it will create jobs in communities that are struggling economically, where people (Indigenous and non-Indigenous) need work. On the other hand, it maintains our dependence on a fossil fuel-based economy, which continues to threaten and destroy the environment, and contribute to the global climate crisis.

5. I do not wish to impose a fixed framework onto the work of decolonizing, Indigenizing, and reconciliation. Rather, Settler Starting Points is a process for consideration, that settler academics may wish to apply and adapt for their own contexts and their individual reflective practices.

6. Here I do not mean anti-racist positions were unsettled, towards affirming racism. Rather, the knee-jerk response to racist speech, the instinct to shame someone for their racism was unsettled and put on hold, to make space for a more learning-centered response to racism.

7. For an example of a safe, collegial community, in which to explore Indigenization, see Yeo et al., 2019.

8. Our facilitation team did not know in advance that this Elder would be attending our workshop.

9. This illustrated storybook is currently under extensive revisions, with plans to submit it for future publication.

10. The initial idea to write the fable was inspired by settler-identifying Robin Attas' story about a deer and a squirrel, which she shared in a presentation in Atlanta, Georgia as part of the ISSoTL Annual Conference 2019 (See Attas, 2019). 
Moving Toward Decolonizing and Indigenizing Curricular and Teaching Practices in Canadian Higher Education

\section{References}

Attas, R. (2019). How Can Educational Developers Spark Social Change? - An Example from Decolonization. International Society for the Scholarship of Teaching and Learning (ISSoTL) Annual Conference. Concurrent Session IV. Thursday, October 10, 2019. Atlanta, USA.

Battiste, M., Bell, L., \& Findlay, L. M. (2002). Decolonizing Education in Canadian Universities: An Interdisciplinary, International, Indigenous research project. Canadian Journal of Native Education, 26(2), 82-201.

Berg, M., \& Seeber, B. K. (2016). The slow professor: Challenging the culture of speed in the academy. University of Toronto Press.

Cardinal, T. (2018). Personal communication. EDEL 595: Teaching Language Arts to First Nations Metis and Inuit. Faculty of Education, University of Alberta. Spring Term, 2018.

CBC Radio. (2020). Day 6: As Wet'suwet'en rail blockades continue, journalist sees echoes of the 1990 Oka Crisis. CBC Radio: https://www.cbc.ca/radio/day6/blockade-standoff-hockey-stickshortage-bernie-impersonator-bill-barr-s-next-move-malcolm-x-doc-and-more-1.5470049/aswet-suwet-en-rail-blockades-continue-journalist-sees-echoes-of-the-1990-oka-crisis-1.5470051

Chambers, C. (2006). "The land is the best teacher I have ever had": Places as pedagogy for precarious times. Journal of Curriculum Theorizing. Fall 2006, 27-38.

Chung, S. H. S. (2019). The courage to be altered: Indigenist decolonization for teachers.

New Directions for Teaching and Learning. Spring 2019(157), 13-25.

Dewey, J. (1938). Experience and education. The Kappa Delta Pi Lecture Series. Touchstone.

Dion, S. D. (2007). Disrupting Molded Images: Identities, responsibilities and relationships - teachers and Indigenous subject material. Teaching Education, 18(4), 329-342.

Easton, L., Lexier, R., Lindstrom, G., \& Yeo, M. (2019). Uncovering the complicit: The decoding interview as a decolonising practice. In Quinn, L. (Ed.), Reimagining curriculum: Spaces for disruption (pp. 149-170). African Sun Media.

Ellis, C., Adams, T. E., \& Bochner, A. P. (2011). Autoethnography: An overview. Historical Social Research, 36(4), 273-290.

Gaudry, A., \& Lorenz, D. (2018). Indigenization as inclusion, reconciliation, and decolonization: navigating the different visions for indigenizing the Canadian Academy. AlterNative,14(3), 218-227.

Hunt, S. (2018). Decolonizing the classroom: Is there space for Indigenous knowledge in academia? Interview on unreserved podcast. CBC Radio. Originally aired Feb. 25, 2018. https://www.cbc.ca/radio/unreserved/decolonizing-the-classroom-is-there-space-for-indigenousknowledge-in-academia-1.4544984

Kirkness, V., \& Barnhardt, R. (1991). First Nations and higher education: The four Rs - Respect, relevance, reciprocity, and responsibility. Journal of American Indian Education, 30(3), 9-16.

Knight, P., Lafrance, M., \& Lassonde, J. (2019). Viens. Art Installation (Exposition) at the Galerie du Nouvel-Ontario. Manifeste de la Place des Arts du Grand Sudbury. Showing February 16-March 30, 2019. https://www.youtube.com/watch?v=bPOf5bL6NQo\&feature=youtu.be 
Kuokkanen, R. (2007). Reshaping the university: Responsibility, Indigenous epistemes, and the logic of the gift. UBC Press.

Marker, M. (2004). The four Rs revisited: Some reflections on First Nations and higher education. In Andres, L. \& Finlay, F. (Eds.), Student affairs experiencing higher education. UBC Press.

Mooney, J. A. (unpublished manuscript). Settler starting points: A process model for non-Indigenous academics moving toward decolonizing curricular and teaching practices in Canadian higher education.

Pidgeon, M. (2014). Moving beyond good Intentions: Indigenizing higher education in British Columbia universities through institutional responsibility and accountability. Journal of American Indian Education, 53(2), 7-28.

Regan, P. (2010). Unsettling the settler within: Indian residential schools, truth telling, and reconciliation in Canada. UBC Press.

Shen, A. (2018). With a shared commitment, Canada's universities take steps towards reconciliation. University Affairs. June, 12, 2018. https://www.universityaffairs.ca/news/news-article/with-a-sharedcommitment-canadas-universities-take-steps-toward-reconciliation/

Simpson, L. B. (2011). Dancing on our turtle's back: Stories of Nishnaabeg re-creation, resurgence, and a new emergence. Arp Books.

The Canadian Press. (2020). Protests over BC Pipeline Continue as Scheer Calls on Trudeau to Act. February 15, 2020. Global News. https://globalnews.ca/news/6550697/wetsuweten-pipeline-protestsmeeting/

Todd, Z. (2017). A note to tenured faculty*. In Urbane Adventurer: Amishkwacî-thoughts of an urban Métis scholar (and sometimes a Mouthy Michif, PhD). December 28, 2017: Uncategorized. https://zoestodd.com/2017/12/28/a-note-to-tenured-faculty/

Todd, Z. (2018). Indigenizing Canadian academia and the insidious problem of white possessiveness. In Urbane Adventurer: Amishkwacî - thoughts of an urban Métis scholar (and sometimes a Mouthy Michif, PhD). May 4, 2018: Uncategorized. https://zoestodd.com/2018/05/04/indigenizing-academiaand-the-insidious-problem-of-white-possessiveness/

TRC. (2015). Truth and Reconciliation Commission of Canada: Calls to Action. Winnipeg, MB: Publication of the Truth and Reconciliation Commission of Canada. http://www.trc.ca

Yeo, M., Haggarty, L., Ayoungman, K., Wida, W., Pearl, C. M. L., Stogre, T., \& Waldie, A. (2019). Unsettling faculty minds: A faculty learning community on Indigenization. New Directions in Teaching and Learning, 2(157), 27-41. 


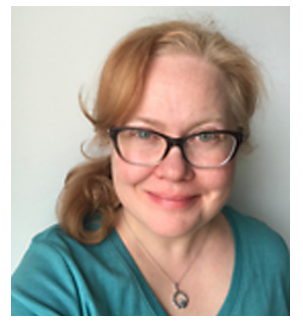

Julie A. Mooney is a Canadian settler of Irish-Scottish ancestry living and working in $\triangleleft \Gamma^{n} \mathrm{~b} \cdot \dot{\Gamma} \triangleleft^{\circ} \mathfrak{n}^{\prime \prime} \Delta \mathrm{b}^{\mathrm{J}}$ (Amiskwaciwâskahikan), Treaty 6 Territory, and the Homeland of the Métis. She is a PhD candidate in Educational Policy Studies at the University of Alberta, specializing in Adult, Community, and Higher Education. Her doctoral research explores how Canadian university professors are learning, with the support of educational developers and local Indigenous community members, to implement institutional policies to Indigenize and decolonize teaching and curricular practices. A 3M National Teaching Fellow and a SSHRC Doctoral Fellow, she is also working on an illustrated storybook exploring reconciliation. 